\title{
Reformulação do Ensino do Direito Civil. Novas Técnicas. Um Programa*.
}

\author{
Antônio Chaves \\ Catedrático de Direito Civil na Faculdade de Direito \\ da Universidade de São Paulo.
}

Não poderia ser melhor a oportunidade deste Seminário nem mais justa e humana sua preocupação pela valorização profissional do advogado.

Bem percebeu a Diretoria da benemérita e representativa Associação dos Advogados de São Paulo que o primeiro passo há de ser uma atualização do ensino do direito principalmente do Direito Civil, para sintonizá-lo com o nosso tempo.

Nem se compreende como o currículo de ramo tão fundamental, verdadeira espinha dorsal do ensino jurídico, arcabouço e base da própria formação profissional, tenha sido reduzido de um semestre.

Numa época em que as conquistas técnicas, como a comunicação via satélite, encolhem as distâncias, em que o próprio decurso do tempo parece atingido pela possibilidade de se fixarem definitivamente os sons e as palavras, outrora de existência tão efêmera, em que os transplantes subverteram todos os conceitos da disponibilidade de partes do corpo humano, um curso não pode mais circunscrever-se a um comentário das noções há mais de 60 anos cristalizadas no Código Civil, com a adjunção de algumas decisões jurisprudenciais, sem ao menos analisá-las, para verificar se são ou não conflitantes entre si.

- Tese apresentada no II Seminário de Valorização Profissional, promovido pela Associação dos Advogados de $S$. Paulo no día 09-08-1975, na Faculdade de Direlto da Universidade de $\mathrm{S}$. Paulo. 
É sem dúvida chegado o momento de focalizar, com certa perspectiva, o programa inteiro e cada um de seus itens, alargando e modernizando o seu conteúdo, num tríplice dimensionamento: metododológico, sociológico e econômico.

Sob o

\section{Ponto de vista metodológico,}

a primeira providência será complementar o Código Civil com toda a série dos diplomas legais mais importantes, dos quais o estudante, durante o curso, e o próprio bacharel, nos primeiros anos após a formatura, não costuma sequer tomar conhecimento.

Mais do que isso: merece, em alguns casos, ser acompanhada a discussão de projetos de leis relacionados com assuntos versados, da análise das Exposições de Motivos, não reproduzidas nos repertórios, e das discussões travadas no Congresso Nacional.

Como não reconhecer que a exegese dos dispositivos legais relativos à propriedade, voltada essencialmente para os imóveis, está desatualizada, tanta importância assumiram os móveis?

Mas, ainda, na propriedade imóvel: não entra pelos olhos a necessidade de se separar o estudo da urbana, com todas as especificações resultantes das leis de zoneamento, dos Códigos de Edificações, da Lei Complementar n. 14, de 08.06.1972, que estabelece as Regiões Metropolitanas de S. Paulo, Belo Horizonte, Porto Alegre, Recife, Salvador, Curitiba, Belém e Fortaleza, da Lei do Silêncio, das leis que procuram combater a poluição?

Como ignorar, já no setor da propriedade agrícola, o Estatuto da Terra, a importância fundamental que passou a ter o módulo rural, o regime diferente a que são submetidas as terras ocupadas pelos silvícolas? 
Terrenos de marinha: eis aí outro tema, inçado de dificuldades e de preconceitos, submetido a uma legislação ultrapassada, para o qual é necessário chamar a atenção dos nossos estudantes.

Sem falar ainda em regime da flora e da fauna, do patrimônio paisagístico, histórico, artístico, das águas e, principalmente, das' minas e jazidas.

Se foi sempre um absurdo não ministrar conceitos essenciais a respeito da energia elétrica, seu regime legal de produção e de distribuição, num país de recursos hídricos como o nosso, - com o problema do petróleo, sua importância, embora tenha crescido extraordinariamente, já deriva para a obra ciclópica empreendida no que diz respeito à energia atômica, não parecendo lógico não fazer uma menção das providências tomadas pelo governo a respeito da matéria, permitindo, por essa forma, com mais facilidade, acompanhar os seus desdobramentos.

Uma seqüêencia bem elaborada, flexível, atenta às aberturas proporcionadas pelas novas conquistas, em todos os setores, é útil não apenas aos estudantes, mas aos próprios profissionais, assoberbados por mil e uma tarefas, tomados por constantes solicitações, que não lhes permitem uma pesquisa organizada, função primordial do professor de direito, que a ela deveria consagrar-se inteiramente.

Mas a velha estrutura dos cursos sobre direitos reais sofreu ainda vários outros impactos: o do condomínio em edificações, exigindo explanaçōes a respeito da administração das partes comuns, da representação, da assembléia geral, das ações e sanções a que pode dar lugar o comportamento dos condôminos, esclarecimentos sobre a Lei n. 4591, de 16.12.1964, sobre incorporações, e toda a legislação complementar, uma análise das diversas modalidades de perda da propriedade que foram se acumulando, além das tradicionais de alienação, renúncia, abandono e perecimento: desapropriação, implicando no problema não resolvido da retrocessão, desapropriação indireta, 
contribuição de melhoria, seqüestro, requisição, confisco, encampação, incorporação ao patrimônio nacional, nacionalização e intervenção.

Esses exemplos são suficientes para que se perceba que está chegado o momento para atualizar os programas para exigir, mais do que apenas um novo dimensionamento, uma completamente nova estruturação de toda a seriação. Do contrário, teremos, ensino não do Direito Civil, mas do Código Civil, quando na verdade tudo tende para ampliar os confins da matéria, na iminência, ainda, de ficar dilatada para Direito Privado.

O curso precisa deixar de ser estático, para tornar-se mais dinâmico, graças ao tempero indispensável da crítica.

Somente tomando os elementos sedimentados no passado, fazendo uma análise minuciosa das disposições vigentes será possível projetar perspectivas para o futuro.

Não existe oportunidade mais adequada do que a dos bancos acadêmicos para fazer despertar, nos futuros profissionais, essa propensão, tão pouco cultuada entre nós, da crítica construtiva dos dispositivos legais, pesquisando textos, fazendo análise comparada, procurando soluções, dando, enfim, uma contribuição para o aperfeiçoamento das instituições.

Mas o impacto das novas condições não se restringe aos Direitos Reais. Assim, na

\section{Parte Geral,}

não pode o Professor de Direito Civil abandonar aos cuidados de seus colegas de Introdução à Ciência do Direito ou de Direito Constitucional a explanação a respeito do instrumental de base do seu trabalho: a própria lei.

Deixando mesmo de lado concepções e métodos pessoais, para ter segurança na explanação do seu programa, precisa mencionar os pressupostos relativos ao modo pelo qual são 
elaborados (ou deveriam ser elaboradas) as leis, sua hierarquia, etc. Há que verificar como está estruturado o sistema legislativo brasileiro, como se integram os circulos concentricos das legislaçōes federal, estadual e municipal.

O próprio estudo do alcance da lei exige uma determinação dos confins do seu âmbito jurisdicional.

Como não proclamarmos o novo dimensionamento decorrente, de um lado, do problema até agora não definitivamente solucionado do ponto de vista internacional, mediante acordo expressivo, da fixação dos limites do mar territorial e da zona contígua, que o governo, em boa hora, dilatou das doze milhas marítimas, a que o decreto-lei n. 553, de 25.04.1969 havia estendido as seis primitivas, para as atuais duzentas, estabelecidas pelo Decreto-lei n. 1098, de 23.03.1970?

Intimamente relacionado a esse está o problema da plataforma submarina, integrada, pelo Decreto n. 28.840, de 08.11.1950, no território brasileiro, e proclamada de jurisdição e domínio exclusivos da União Federal.

E o espaço sideral?

Sua conquista deixou, em menos de 15 anos, de ser um devaneio da ficção científica para tornar-se problema do dia-adia, exigindo que se verifique como devem ser demarcados os limites laterais da soberania aérea nacional, fator importantíssimo para, entre muitos outros, definir-se de que modo devem ser distribuídas as frequiências de emissões de ondas de radiodifusão, das concessões do uso dos canais, dos satélites mortos, das consequiências dos acidentes e prejuízos que podem ocasionar.

Não pode ser ignorado o problema, depois que o Governo, pelo Decreto n. 64 362, de 17.04. 1969 promulgou o "Tratado sobre Princípios Reguladores das Atividades dos Estados na Exploração e Uso do Espaço Cósmico, inclusive a Lua e demais Corpos Celestes." 
O estudo das pessoas naturais leva à análise, além dos temas tradicionais, da condição jurídica do estrangeiro, tema tão controvertido, importante, quão dispersivamente versado, e à análise dos direitos fundamentais da pessoa natural, que podem ser discriminados nos denominados direitos do homem, entre os mais importantes dos quais estão os à vida, à integridade física, sobre o próprio corpo e partes do mesmo (transplantes), à liberdade, de ação, e à propriedade; dos direitos da personalidade propriamente ditos: à honra, ao nome, à própria imagem, à liberdade de manifestação do pensamento, à liberdade de consciência e de religião, à reserva sobre a intimidade, ao segredo, moral de autor e à instrução e cultura.

E com relação às pessoas jurídicas? Tenho afirmado que assumem tão dominante importância que vivemos o século das pessoas jurídicas, se é que não vivem elas o nosso século.

Quem não se dá conta de quanto tumultariamente temse processado o seu aparecimento e o seu desenvolvimento, como nos sentimos perdidos nesse cipoal em que nem sempre o próprio legislador define com segurança quando uma pessoa é de direito público interno ou de direito privado?

Daí a necessidade de, bem ponderando os dados fornecidos pelo direito positivo, fazermos um elenco das pessoas jurídicas de direito público interno: União, Estados, Distrito Federal, Territórios Federais, Regiões Metropolitanas, Municípios, partidos políticos, autarquias, fundações públicas, estabelecimentos de serviço público e instituiçães financeiras públicas, e ordens profissionais, para abordarmos, embora ligeiramente, seu regime jurídico, e aprofundarmos o tema, de tanta importância da sua fiscalização.

Isso nos levará, fatalmente, a tentarmos uma sistematização também das pessoas jurídicas de direito privado (verificando sua constituição, seus requisitos, órgãos, estatutos, direitos e deveres das próprias pessoas e dos seus membros) e a uma classificação, separando as fundações privadas das associações em geral, das de utilidade pública. Estará aberto en- 
tão o caminho para a análise das principais associações, em espécie: religiosas, esportivas, recreativas, etc., pias, morais, científicas, literárias, instituições de educação ou de assistência social, cooperativas.

Seguir-se-á o estudo das empresas, das empresas públicas, das sociedades simples, das de economia mista, das sociedades que necessitam prévia autorização para se constituirem, das que dependem de autorização prévia para funcionarem, das sociedades comerciais, cujas formas o art. 1364 do Código Civil autoriza revestirem as sociedades civis, inclusive as anônimas.

Entrar-se-á, então, no estudo tão relevante dos interesses não constituidos em pessoas jurídicas, no tema atualíssimo das transformações dessas pessoas, e no escaldante da participação do capital estrangeiro, das pessoas jurídicas estrangeiras, das transnacionais ou multinacionais, etc.

Como não reconhecer, enquanto não for criada uma cadeira de Notariado, que toda a matéria relativa aos registros deve ser intercalada, em tópicos adequados? Seu estudo irá demonstrar a existência de falhas e lacunas. Assim, analisado o registro das pessoas físicas, surgirá a indagação de como é levado: a efeito o registro das pessoas jurídicas, que não se circunscreve às sociedades comerciais. Perceber-se-á, então, como é dispersivo, descentralizado e deficiente, clamando por uma reformulação de base.

Assim, também, se é bem estruturado o sistema do registro de imóveis (o que não impede a consideração de ulteriores aperfeiçoamentos), a mesma preocupação metodológica imporá a conveniência de lançar um olhar para o registro de móveis.

Ferceber-se-ão então o quanto foi negligenciada pelo. legislador essa parte, que regula, sem qualquer uniformidade de vistas, em diplomas legais diferentes, o registro de embarcações, o registro aeronáutico, o registro de veículos automotores, o registro da propriedade literária e artística, o registro de animais domésticos, o registro dos bens e valores que as pessoas físicas ou jurídicas possuirem no exterior, o registro 
de antigüidades, obras de arte, manuscritos e livros antigos, de comércio de pedras preciosas, metais nobres e outros minérios, de letras de câmbio e notas promissórias, etc.

Se passarmos para 0

\section{Direito das Obrigações,}

a necessidade de uma reformulação aparecerá ainda mais evidente.

Nunca entendi porque é que, existindo uma Parte Geral do Código Civil, com normas introdutórias relacionadas a cada uma das Partes Especiais, deveria existir ainda uma Parte Geral do Direito das Obrigaçães. A ser assim, não se poderiam dispensar Partes Gerais para os Direitos Reais, para o Direito de Família, para o Direito das Sucessões.

Incluir, como faz o Código Civil, o pagamento e suas diferentes modalidades entre os "Efeitos das Obrigações", constitui um desvio flagrante, pois ninguém negará que o pagamento é uma das modalidades de extinção das obrigações, devendo pois passar para o capítulo de encerramento, e não estar no começo das disposições.

Como explicar que sejam estudados antes os efeitos das obrigações, do que cada uma das suas diferentes modalidades?

Essa consideração nos conduz à averiguação de quais são as causas geradoras das obrigações.

Verificaremos, então, a posição assimétrica ocupada pelos contratos, importante, sim mas não exclusiva fonte das obrigaçães, a dominar excessivamente o livro III, da Parte Especial do Código Civil, arts. 1079 a 1504.

Ninguém contesta a relevância do rol aí estabelecido, mas que exige a compelmentação de outros contratos não incluidos, ou necessitados de desdobramentos mais específicos (compra c venda de bens imóveis e de bens móveis: aqueles ainda em 
imóveis não loteados e loteados (rurais e urbanos) : estes, focalizando as diferentes modalidades especiais: venda sob reserva de domínio, mediante poupança, a contento, de fornecimento ou provisão, alienação fiduciária, etc.) .

O estudo da locação também precisa ser reestruturado, complementando-se a de coisas imóveis, em locação de prédios urbanos (residenciais, comerciais ou industriais e mistos) e de prédios rurais, e ainda, estudando-se a locação de coisas móveis ("leasing"), da antigamente denominada locação de serviços, hoje, contrato de trabalho, implicando uma série de problemas atualíssimos.

Entre os contratos novos, temos os de agências e distribuição, expedição ou despacho, franquia, informática, comunicações, contratos bancários, turismo, agenciamento, propaganđà, divulgação, etc.

Surgirá também aqui o problema do registro dos contratos, a que se atribui cada vez maior importância, devido às maiores facilidades de fiscalização que oferecem.

Mas o fato é que os contratos constituem apenas uma das causas geradoras das obrigações, o que nos obriga a abrir o espaço que a responsabilidade civil exige, muito além dos poucos artigos (1518 a 1532) reservados pelo Código Civil às obrigações por atos ilícitos.

Aí está: o velho alcacer feudal do direito das obrigações terá que ser derrubado, para dos escombros erigir-se, com os mesmos elementos, outra construção arejada, espaçosa, dinâmica, dimensionada para o futuro. Ao arquiteto da nova construção caberá dividí-la em quatro partes: I. estrutura, classificação e modalidades das obrigações; II causas geradoras (compreendendo: 1 as decorrentes de declaração unilateral da vontade, 2 . os contratos, 3 . responsabilidade civil, 4 risco, 5. responsabilidade penal); III. liquidação das obrigações; IV. extinção. 
Será então possível dar a cada uma delas um conteúdo mais completo e mais orgânico, separando, na primeira parte, os conceitos introdutórios realmente estritamente indispensáveis e próprios, analisando na segunda, não apenas as mais importantes modalidades contratuais, mas também a interpretação, garantia, efeitos dos contratos, sua transformação e transmissão, o: não aperfeiçoamento, a nulidade, o retadamento, a inexecução e o desfazimento dos contratos; distinguindo a responsabilidade civil relacionada com os contratos (pré-contratual, contratual e pós contratual) da que decorre dos atos culposos em suas diferentes modalidades, entre estes incluindo-se a decorrente desse verdadeiro flagelo que são os acidentes nos transportes, e ampliando-se o estudo da decorrente atividade profissional, teoria do risco, etc.,

$\mathrm{Na}$ terceira parte será abordada a relação da causalidade entre culpa e dano, os temas atualíssimos do dano moral, do dano estético, da atualização monetária.

Na quarta, finalmente, os modos gerais e especiais de extinção: das obrigações, as várias modalidades de pagamento, sua prova, impossibilidade de pagamento e suas conseqüências.

Material destinado a estudantes, não pode, evidentemente, atingir grande profundidade.

Mas é possível, ou melhor, é indispensável traçar pelo menos as grandes linhas doutrinárias, indicar a bibliografia fundamental mais acessível, apontar casos de jurisprudência que possam ser considerados típicos, fornecer, enfim, o manuseio do primeira ferramente para que o futuro profissional possa não sentir-se muito embaraçado quando a vida prática exigir o seu pronunciamento sem perda de tempo.

O mesmo sopro renovador terá que manifestar-se com relação aos direitos reais, já apontados, ao direito de família, muito menos conservador do que poderia parecer à primeira vista. Tem que ser revista a concepção que considera o casamento religioso como mero concubinato, tem que ser reestu- 
dada a matéria relativa aos efeitos civis do casamento religioso, as sanções penais e civis relativas ao casamento, a condição da mulher casada, a nova sistematização, tão deficiente, do regime de bens no casamento, as anomalias decorrentes da inexistência do divórcio, como os "casamentos por contrato" e o concubinato, a guarda e proteção dos filhos, a filiação ilegítima, a harmonização entre as duas instituições da adoção e da legitimação adotiva, etc., etc.

\section{Aulas Ministradas pelos Alunos.}

Mas a aspiração metodológica fundamental objetiva modificar a mentalidade dos estudantes de aplicar-se apenas na semana que precede aos exames, com o inconveniente ben conhecido do Esquecimento completo na semana subseqüente.

Se 0 corpo discente quer hoje "diálogo" com os mestres, e não mais os monótonos e nonocórdios monólogos, o certo é que discussões proveitosas só podem ser estabelecidas quando também a outra parte tenha aquele mínimo de conhecimento que permita formar um ponto de partida para ulterior desenvolvimento.

A distribuição da matéria em volumes de pequeno formato, de fácil manuseio, permite uma inversão nos métodos tradicionais: o professor, em cada aula, poderá solicitar dos alunos a leitura do "ponto" seguinte, a ser discutido em classe, com a ajuda de monitores, que irão tomando nota do grau de conhecimento revelado pelos interpelados.

A intenção é fazer com que, em vez de "dar" sistematicamente aulas, passe o professor a "recolher" pelo menos uma parte das mesmas, obtendo, por essa forma, uma participação muito mais ativa e proveitosa, pois o espírito de emulação fará com que os alunos se interessem mais pelas explanações de seus colegas do que pela de seus mestres, dispensando até mesmo, em parte, provas e provinhas escritas. 
Para dar uma idéia mais completa, anexamos, como parte integrante do presente depoimento, o programa que elaboramos, aberto a qualquer sugestão ou crítica construtiva.

Com a ambição de ser um programa de base, tinha que ser extenso, para que resultasse orgânico, e, tanto quanto possível, completo, tendo sido calculado para fornecer, para cada semestre, o número de aulas exigido por lei, com margem ainda para as indispensáveis aulas práticas.

Resta abordar, rapidamente, os

\section{Enfoques Sociológicos e Econômicos,}

A Exposição de Motivos apresentada em janeiro de 1972 pela comissão de juristas incumbida de preparar a reformulação do currículo mínimo dos cursos de Direito, e que proclamou o Direito Civil matéria profissional obrigatória, entregue ao Diretor do Departamento de Assuntos Universitários do Ministério da Educação e Cultura, ressaltou que "para o aluno ter uma visão histórica verdadeira do seu tempo é preciso darlhe instrumental sociológico e econômico, complementado por mudanças nos métodos de ensino".

Admitiu-se ser o atual currículo fator de desajustamento entre o ensino jurídico e a realidade social, representando um obstáculo às soluções inovadoras, aptas a conduzir as Faculdades de Direito ao seu papel de liderança e a promover a formação de bacharéis capacitados às missões profissionais.

Como não reconhecer a importância reservada às pessoas jurídicas?

Não foi ainda realizado um estudo atualizado de todas as possibilidades que oferecem. Já é tempo de rever conceitos sediços de que elas interessam apenas aos seus sócios, para reconhecer que mesmo as que não sejam de utilidade pública, quando digam respeito a um grande número de interessados, devam ser submetidas a uma fiscalização mais rigorosa. 
A diversidade que elas podem oferecer há de ser fatalmente levada em conta quando, num futuro que não deve estar muito distante, perceber o legislador a necessidade de reformular completamente a matéria relativa ao registro de modo a permitir semelhante fiscalização.

O deputado I. G. De Araujo Jorge, ao justificar o seu projeto de lei n. 521, de 1971, que "Cria exigências para o registro civil das entidades de assistência ao menor", aborda problema dos mais dolorosos ao demonstrar que um terço, talvez, das obras assistenciais particulares são clandestinas, desconhecidas, portanto, da fiscalização. Acentua ser grande o número de instituições criadas, sob o rótulo de proteção, que, vivendo à margem da lei, e com fins lucrativos, acabam por se transformar em verdadeiros atentados ao menor, explorando-os e mantendo-os em condições desumanas de desamparo.

Essas, senhores, as sugestões que vinte anos de magistério de direito civil me autorizam apresentar. Esse o programa que me parece compatível com a atual realidade brasileira levando em conta suas peculiaridades e suas necessidades, numa tentativa de inovação de nossos métodos de ensino, perfeitamente em sintonia com o espírito da campanha da Associação dos Advogados de São Paulo, em prol da valorização profissional.

$$
\begin{gathered}
\text { Introdução e Parte Geral } \\
\text { Parte I } \\
\text { Introdução } \\
\text { Título I }
\end{gathered}
$$

\section{Princípios Fundamentais do Direito.}

Capítulo I

O direito como norma de comportamento

01. As normas relevantes do comportamento do homem: religião, moral, direito.

02. Direito. Etimologia. Conceito. 
Capítulo II

Direito objetivo

03. Divisões. Caracteres.

04. Meios de expressão (fonte imediata) do direito objetivo: A. a lei. Hierarquia das leis. $\mathrm{O}$ "standard" jurídico. Lacunas da lei. Meios de integração: a. analogia. b. Equiidade.

05. Normas introdutórias ao Código Civil. Eficácia da lei no tempo. A teoria do fato realizado (direito adquirido) .

06. Eficácia da lei no espaço. O mar territorial.

07. Interpretação da lei.

08. Meios de expressão (fontes mediatas) do direito objetivo: B. Costumes. C. Princípios gerais de direito. Importância da doutrina, da jurisprudểncia, do direito comparado.

Capítulo III

Direitos subjetivos

09. Conceito, natureza. Elementos, categorias. Extensão.

Capítulo IV

$\mathrm{O}$ direito natural

10. Histórico. Importância, caracteres. Função dos ideais de conduta.

Título II

Direito Civil. Conceito. Evolução Histórica. Conteúdo.

Capítulo I

Introdução

11. Conceito. Evolução do Direito Civil em geral. 


\section{Capítulo II}

Formação histórica do Direito Civil brasileiro

12. a. Fase colonial.

13. b. Fase imperial. c. O período da pré-codificação civil.

14. d. Codificação. Os trabalhos de elaboração do Código Civil brasileiro.

15. Características, significação e importância do Código Civil pátrio. A ação do tempo. A arte de fazer leis.

Capítulo III

A teoria da unificação do direito privado.

16. Argumentos contra e a favor. Histórico da doutrina unificado.

17. A doutrina unificadora no Brasil.

\section{Capítulo IV}

Os trabalhos de reformulação da legislação privada no Brasil

18. a. Anteprojeto da Lei Geral de Aplicação das Normas Jurídicas.

b. Anteprojeto do Código de Menores.

c. O Projeto Orlando Gomes.

d. O Projeto do Código de Obrigações.

19. e. O Projeto do Código Civil de 1975.

Capítulo V

Conteúdo do Direito Civil

20. Classificação das normas do Direito Civil. Sistema do Código Civil brasileiro. Tendências atuais. A cibernética. Oportunidade da reforma. 


\section{Parte II}

Parte Geral do Código Civil.

Disposição preliminar. Do sujeito do direito.

\section{Título I \\ Noções Introdutórias.}

21. Objeto da Parte Geral do Código Civil. Disposição preliminar.

\section{Título II}

\section{Do Sujeito do Direito.}

\section{Capítulo I \\ Pessoas Naturais}

Seção I

Estado, personalidade, capacidade. Proteção aos incapazes

22. Pessoa natural. Noção. Começo de existência. Condição jurídica do nascituro.

23. O estado das pessoas.

24. Personalidade, discernimento, capacidade. Dos absoluta e dos relativamente incapazes. Condição jurídica do estrangeiro.

25. A proteção aos incapazes e aos menos favorecidos. Representação e assistência. Cessação da incapacidade.

Os direitos fundamentais da pessoa natural.

("Direitos do homem")

25. Direitos: a. à vida. b. đ̇ integridade física. c. Sobre o próprio corpo e partes do mesmo (transplantes). d. A liberdade. e. De ação. f. À propriedade. 


\section{Seção II \\ Os direitos da personalidade}

27. Direitos: a. à honra. b. Ao nome. c. À própria imagem. d. À liberdade de manifestação do pensamento. e. A liberdade de consciência e de religião. $\mathrm{f}$. À reserva sobre a intimidade. g. Ao segredo. h. Moral de autor. i. À instrução e à cultura.

\section{Seção IV \\ Domicílio das pessoas naturais.}

28. Noção de domicílio. Espécies. Importância. Pluralidade de domicílios. Residência.

\section{Seção V}

Fim da pessoa natural

29. Morte e presunçāo de morte. Comoriência.

Seção VI

Registro

30. Os registros públicos em geral. Registro civil das pessoas naturais.

$$
\begin{gathered}
\text { Capítulo II } \\
\text { Pessoas jurídicer }
\end{gathered}
$$

31. Conceito, natureza, classificação. Elementos constitutivos.

\section{Seção II}

Pessoas jurídicas de Direito Público.

32. Pessoas jurídicas de Direito Pública externo. 
33. Pessoas jurídicas de Direito Público interno.

34. Pessoas júricas de Direito Privado. Constituição. Requisitos. Órgãos. Estatutos. Direitos da pessoa jurídica. Direitos e deveres dos membros. Necessidade de uma reformulação dos dispositivos legais.

35. Classificação. Fundações. Associações em geral. As associações de utilidade pública.

36. Associações religiosas; esportivas, recreativas, pias, morais, científicas, literárias; instituiçōes de educação ou assistência social; cooperativas.

37. Empresas. Sociedades simples. Sociedades de economia mista.

38. Outras sociedades com características próprias.

39. Transformação e extinção das pessoas jurídicas.

40. Domicílio e registro das pessoas jurídicas.

$$
\begin{gathered}
\text { Parte III } \\
\text { Do objeto do direito } \\
\text { Título I }
\end{gathered}
$$

Noções Introdutórias.

41. Coisa, bem, propriedade, domínio, patrimônio.

$$
\text { Título II }
$$

\section{Dos Bens Objetivamente Considerados.}

42. Classificação. a. Bens imóveis.

43. b. Bens móveis. Espécies.

\section{Título III}

Dos Bens Reciprocamente Considerados.

44. Bens divisíveis e bens indivisíveis. 


\section{Título IV}

\section{Dos Bens Subjetivamente Considerados.}

45. Bens públicos.

46. Bens particulares.

47. Coisas que estão fora do comércio.

48. O bem de família.

\section{Título V \\ Registro dos Bens.}

49. Registro de imóveis.

50. Registro de móveis.

$$
\begin{gathered}
\text { Parte IV } \\
\text { As relações de direito } \\
\text { Título I }
\end{gathered}
$$

Aquisição, Fruição, Modificação e Transmissão do Direito.

51. Aquisição do direito. $\mathrm{O}$ interesse legítimo. $\mathrm{O}$ direito adquirido. (remissão ao ponto $5^{\circ}$ ) .

$$
\text { Título II }
$$

\section{Dos Fatos Jurídicos.}

52. Noção. Classificação.

$$
\text { Título III }
$$

Dos Atos e dos Negócios Jurídicos.

$$
\begin{gathered}
\text { Capítulo I } \\
\text { Generalidades. }
\end{gathered}
$$

53. Ato jurídico e negócio jurídico. Modalidades dos atos jurídicos. 


\section{Capítulo II}

Estrutura do negócio jurídico

54. Pressupostos e elementos constitutivos.

55. Elemento constitutivo subjetivo: a manifestação da vontade. O silêncio como manifestação da vontade.

56. A boa fé e a sua proteção.

57. Elementos objetivos: a. objeto. b. Causa.

58. Elementos naturais e acidentais. a. condição. b. Termo. c. Modo ou encargo.

\section{Capítulo III Forma}

59. Declarações de vontade que dependem e declarações de vontade que não dependem de forma especial. A ficção. A teoria da aparência. Legitimação.

\section{Capítulo IV \\ Prova e registro}

60. Prova dos atos jurídicos. Documentos públicos e documentos particulares. Registro de títulos e documentos.

\section{Capítulo V}

Defeitos dos atos jurídicos

61. Erro ou ignorância.

62. Dolo.

63. Coação.

64. Simulação.

65. Fraude contra credores.

66. Nulidades: atos inexistentes e atos nulos.

67. Atos anuláveis e sua convalidação. 


\section{Capítulo VI}

Efeitos

68. Efeitos dos atos jurídicos.

\section{Título IV}

\section{Dos Atos Ilícitos.}

69. Violação de direitos. Reparabilidade.

70. Causalidade. Imputabilidade, culpabilidade e responsabilidade. Sanções civis e sanções penais.

\section{Parte V}

Coerção social (exercício, defesa e conservação dos direitos)

71. O exercício do direito e suas limitações.

72. A defesa e a conservação. Estado de necessidade. A legítima defesa.

73. Enriquecimento sem causa.

74. Ação de simulação. Lesão. Abuso de direito. Ação pauliana.

\section{Parte VI}

Extinção e perda dos direitos

75. A prescrição. Prazos.

76. Causas que impedem e causas que suspendem a prescrição.

77. Causas que interrompem a prescrição.

78. Renúncia ao direito.

79. Extinção do direito.

80. Decadência. 


\section{Direito das ObRigações}

\section{Parte I}

Estrutura, classificação e modalidades das obrigações

\section{Título I \\ Conceitos Introdutórios.}

01. Obrigação. Fonte das obrigações.

02. Direito das Obrigações. Generalidades. Distinção dos direitos reais. Evolução histórica. Tendência para regulamentação autônoma.

\section{Título II \\ Estrutura das Obrigações.}

03. Elementos oonstitutivos: a. sujeito ativo. b. Sujeito passivo. c. Objeto. d. Vínculo.

Título III

\section{Classificação e Modalidades.}

04. Classificação geral. Obrigações naturais.

05. Obrigações de dar: a. coisa certa. b. Coisa incerta.

06. Obrigações de fazer e obrigações de não fazer.

07. Obrigações alternativas, facultativas, condicionais, a termo.

08. Obrigações divisíveis e obrigações indivisíveis.

09. Obrigações solidárias: a. solidariedade ativa. b. Solidariedade passiva.

10. Obrigações "ob rem" ou "propter rem". 


\section{Parte II}

Causas geradoras das obrigações.

Título I

Das Obrigações por Declaração Unilateral da Vontade.

11. Doutrina da vontade unilateral. Títulos ao portador.

12. Promessa de recompensa. Concurso.

\section{Título II}

Dos Contratos.

\section{Capítulo I}

Dos contratos em geral

13. Noção de contrato. Princípios gerais. Evolução. Tendência para os contratos coletivos. Contratos normativos, contratos-tipo, contratos de adesão.

14. Requisitos subjetivos do contrato: a. capacidade das partes. b. Acordo, ou mútuo consentimento.

15. Formação do contrato. Negociações preliminares. Policitação ou proposta. Opção. Aceitação.

16. Requisitos objetivos do contrato: a. objeto. b. Forma. Contratos verbais, tácitos ou presumidos.

17. Promessa de contratar. Contrato preliminar.

18. Classificação dos contratos.

19. Contratos aleatórios.

20. Contratos concluídos pelo Poder Público.

\section{Capítulo II}

Dos contratos em espécie

21. Estipulação a favor de terceiro. Promessa de fato ou coisa de terceiro. 
22. Compra e venda. Disposições gerais. Venda pelo poder público.

23. Compra e venda de bens imóveis. Vendas ad corpus e ad mensuram. Formalidades.

24 Modalidades especiais: imóveis não loteados. a. Promessa bilateral com faculdade de arrependimento. b. Promessa bilateral sem faculdade de arrependimento. Loteamentos não inscritos.

25. Compromisso de compra e venda de imóveis loteados: a. rurais. Colonização.

26. b. Urbanos.

27. Venda a prestações mediante sorteio e distribuição de prêmios. Retrovenda. Pacto de melhor comprador. Perempção ou preferência.

28. Compra e venda de bens móveis. Modalidades especiais: a. venda sob reserva de domínio. b. Venda mediante poupança. c. Venda a contento. d. Contrato de fornecimento ou provisão. e. Alienação fiduciária. f. Contrato estimatório.

29. Troca ou permuta. Câmbio.

30. Doação.

31. Locação. Locação de coisas. Disposições gerais.

32. Locação de prédios. Preceitos gerais. Locação de prédios urbanos: residenciais, comerciais ou industriais, mistos.

33. Arrendamento rural.

34. Locação de coisas móveis. "Leasing".

35. Contrato de trabalho (locação de serviços).

36. Empreitada.

37. Empréstimo: comodato, mútuo.

38. Depósito. 
39. Administração, representação, mandato.

40. Comissão. Agência e distribuição. Expedição ou despacho. Franquia.

41 Mediação ou corretagem.

42. Incorporação edilícia.

43. Gestão de negócios alheios.

44 Reprodução e edição.

45. Representação e execução de obras dramáticas, dramático-musicais e musicais.

46. Sociedade.

47 Parceria rural.

48. Constituição de renda.

49 Seguro.

50. Jogo e aposta.

51 Garantia e fiança.

52. Transporte.

53. Albergaria.

54. Turismo.

55. Financiamento. Consórcio.

56. Conta corrente. Contratos bancários.

57. Contrato de risco.

58. Estacionamento.

59. Comunicações.

60. Propaganda, informação e divulgação.

Capítulo III

Interpretação, garantia, efeitos dos contratos

61. Interpretação dos contratos. 
62. Meios de conșervação e garantia: a. registro. b. arras. c. Cláusula pénal.

63. d. Direito de retenção. e. Rejeição da coisa por vício redibitório. f. Evicção.

64. Efeitos dos contratos entre as partes e em relação a terceiros.

\section{Capítulo IV}

Transformação e transmissão dos contratos

65. Modificações objetivas e modificações subjetivas dos contratos.

66. Cessão. Cessão de crédito. Cessão de crédito litigioso. Assunção de débito. Procuração em causa própria.

67. Conversão e transferência de situações contratuais. Cessão de posição acionária.

\section{Capítulo V}

Não aperfeiçoamento, retardamento, inexecução, desfaziamento e nulidade dos contratos

68. Inexistência, nulidade, anulabilidade e ineficácia dos contratos.

69. Resolução dos contratos por vontade das partes. Inadimplemento involuntário. Distrato, resolução, dissolução por disposição legal.

70. Álea. Caso fortuito e força maior. Imprevisão. Inexecução e suas conseqüências.

\section{Capítulo I}

Responsabilidade Civil

Responsabilidade relacionada com os contratos

71. Generalidades. Evolução. Responsabilidade pré-contratual. 
72. Responsabilidade contratual. Responsabilidade pós-contratual.

\title{
Capítulo II \\ Responsabilidade Extra-contratual
}

73. Responsabilidade das pessoas físicas. Atos culposos por fato próprio. Atos culposos por fato de terceiro.

74. Responsabilidade das pessoas jurídicas.

75. Atos culposos por fato de animais e de coisas.

76. Os transportes. As prestações gratuitas.

77. A atividade profissional. Demais atividades.

\section{Capítulo III}

Risco

78. O risco como causa geradora de obrigações. O seguro obrigatório.

\author{
Capítulo IV \\ Responsabilidade penal.
}

79. Delitos. Violação dos direitos fundamentais da pessoa.

80. Atos ilícitos.

\section{Parte III \\ Liquidação das obrigações \\ Título I \\ O Prejuízo e sua Averiguação.}

81. Relação de causalidade entre culpa e dano.

82. Reparação. Perdas e danos.

83. O dano moral. O dano estético. 


\section{Título II \\ Liquidação do Prejuízo.}

84. Garantias de indenização.

85. Liquiđação voluntária.

86. Liquidação legal e liquidação judicial.

87. Mora e suas conseqüiências.

88. Atualização monetária.

89. Concurso de credores.

90. Causas de preferência no pagamento.

\section{Parte IV \\ Extinção das obrigações}

\section{Título I}

\section{Pagamento.}

91. Cumprimento das obrigações. Modos gerais e modos especiais. Pagamento. Noção. Quem deve pagar. A quem se deve pagar.

92. Objeto do pagamento. Lugar. Tempo. Escala móvel.

93. Pagamento por consignação.

94 Pagamento com subrogação.

95. Dação em pagamento. Imputação do pagamento.

96. Pagamento indevido. Prova do pagamento. Quitação. Despesas.

97. Novação. Compensação.

98. Transação. Compromisso.

99. Confusão. Renúncia de dívidas. Prescrição do direito.

100. Impossibilidade de pagamento. Prescrição da ação. 
Direitos Reais

Parte I

Enumeração e classificação.

Título único

\section{Conceitos Introdutórios.}

01. Direitos das coisas - direitos reais. Diferenças entre os direitos reais e os das obrigações. Enumeração e classificação dos direitos reais. Caracteres essenciais.

\section{Parte II}

Posse

\section{Título I \\ Introdução.}

02. Origem e evolução histórica. Teorias principais. Conceito. Natureza jurídica. Posse e detenção.

\section{Título II}

\section{Estrutura. Elementos.}

03. Estrutura da posse. Elementos: a. sujeito. Convergência de sujeitos ou composse. Codetenção.

04. b. Objeto. Posse de coisas corpóreas. Posse dos direitos reais.

05. A questão da posse de direitos pessoais.

06. c. Relação possessória. Extensão e qualificação da posse. A posse de coisas móveis e a posse de coisas imóveis. 
Posse direta e posse indireta. Posse justa. Posse de boa fé. Posse nova e posse velha.

\section{Título III \\ Aquisição, Efeitos, Conservação.}

07. Aquisição, transmissão, acessão. Atos que não induzem à posse.

08. Efeitos da posse. Direitos do possuidor.

09. Conservação, modificações, perda e recuperação da posse.

10. Proteção possessória.

\section{Parte III \\ Propriedade \\ Título I \\ Generalidades.}

11. Evolução, natureza e fundamento do direito de propriedade. Propriedade e domínio.

Título II

Da Propriedade Imóvel.

Capítulo I

Aquisição

12. Caracteres. Limitações naturais, legais, e decorrentes da vontade do titular.

13. Modos de aquisição da propriedade imóvel: a. transcrição. 
14. b. Acessão: ilhas, aluvião, avulsão, álveo abandonado, construções e plantações.

15. c. Usucapião. d. Direito hereditário. e. Casamento. f. Adjudicação.

\section{Capítulo II}

Regimes especiais

16. a. Propriedade urbana.

17. b. Propriedade rural. c. Terras ocupadas pelos silvícolas. d. Terrenos de marinha.

18. e. Minas e jazidas.

19. f. Águas. g. Energia.

20. h. Flora. i. Fauna. j. O patrimônio paisagístico, histórico e artístico.

\section{Capítulo III}

\section{Direitos de vizinhança}

21. Uso nocivo da propriedade. Limites entre prédios. Direitos de tapagem. Árvores limítrofes. Passagens forçadas. Árvores limítrofes. Passagem forçada. Águas.

22. Direito de construir.

\section{Capítulo IV}

Condomínio

Seção I

Generalidades

23. Conceito, natureza, espécies. 


\section{Seção II}

Condomínios de natureza especial

24. a. Em paredes, cercas, muros e valas. b. Compáscuo. c. De águas. d. De imóveis enfitêuticos.

25. Administração do condomínio. Extinção.

\section{Seção III}

\section{Condomínio em edificações}

26. Conceito legal do instituto. Constituição. Direitos e deveres dos condôminos.

27. Administração das partes comuns. Representação. A assembléia geral. Ações e sanções. Extinção do condomínio.

\section{Capítulo. V}

Incorporações

28. Diretrizes da Lei n. 4591, de 16.12.1964. O incorporador. O proprietário do terreno. $\mathrm{O}$ construtor. $\mathrm{O}$ corretor. $\mathrm{O}$ adquirente das unidades isoladas. Obrigações e direitos.

29. Da construção de edifícios em condomínio. Da construção por empreitada. Por administração. Infrações.

\section{Capítulo VI}

Propriedade resolúvel.

30. Conceito. Natureza jurídica. Modalidades. Efeitos.

Capítulo VI

Perda da propriedade imóvel

31. Por: a. alienação. 
32. b. Renúncia. c. Abandono. d. Perecimento do imóvel.

33. e. Desapropriação. A retrocessão.

34. f. Desapropriação indireta. A contribuição de melhoria.

35. g. Seqüestro. h. Requisição. i. Confisco. j. Encampação. k. Incorporação ao patrimônio nacional. 1. Nacionalização. m. Intervenção e liquidação extrajudicial.

\section{Título III}

\section{Da Propriedade Móvel.}

\section{Capítulo I}

\section{Generalidades. Modalidades especiais}

36. A propriedade cartular. $\mathrm{O}$ automóvel. $\mathrm{O}$ avião. $\mathrm{O}$ navio. A clientela. $O$ fundo de comércio.

\section{Capítulo II \\ Aquisição}

37. Modos originários de equisição: ocupação (caça e pesca, invenção, tesouro) .

38. Modos derivados: a. tradição. b. Especificação. c. Confusão, comissão, adjunção.

39. d. Usucapião.

\section{Capítulo III \\ Perda}

40. Perda da propriedade móvel. Recuperação.

Capítulo IV

Propriedade literária, cienfica e artística

41. Direito de autor. Noção, natureza, fundamento. Sujeito, objeto, atributos. 
42. Limites. Transmissão causa-mortis e inter-vivos. Domínio público.

43. Violações. Proteção e defesa.

\section{Parte IV \\ Direitos reais. \\ Título I \\ Direitos Reais Sobre Coisas Alheias.}

44 Definição, natureza jurídica, constituição, classificação.

45. Enfiteuse. Natureza jurídica. Modos de constituição. Direitos e deveres do foreiro e do senhorio. Extinção.

46. Servidões prediais. Noção geral. Classificação. Constituição e extinção.

47. Usufruto. Constituição. Direitos e obrigações do usufrutuário e do proprietário. Extinção.

48. Uso. Habitação.

49. Rendas constituídas sobre imóveis.

50. Direito de preferência. Ônus fiscais. Propriedade minerária. Promessa irretratável de venda (remissão). Direito real resolúvel de uso de terrenos públicos ou particulares. A questão do direito de superfície.

\section{Título II \\ Direitos Reais de Garantia.}

51. Noção. Histórico. Conceito. Espécies. Disposições comuns. Efeitos.

52. Penhor. Elementos. Direitos e deveres do devedor e do credor. Espécies: a. penhor legal. b. Penhor rural. c. Penhor mercantil. 
53. d. Penhor industrial. A cédula industrial pignoratícia. e. Penhor de direitos. Caução de títulos de crédito. Inscrição e extinção do penhor.

54. Anticrese. Noção. Direitos e deveres do credor e do devedor anticréticos.

55. Hipoteca. Generalidades. Antecedentes históricos. Natureza e caracteres. Constituição: a . elementos pessoais. b. Elementos reais. c. Elementos formais. Pluralidade de hipotecas.

56. Hipotecas típicas: a convencional. Células hipotecárias.

57. b. Legal. c. Judicial.

58. Hipotecas especiais: a. das vias férreas. b. Dos navios, ou marítima. c. Aeronáutica.

59. Extensão, conteúdo, efeitos da hipoteca. Modificações: a. transmissão. b. remição. c. Subrogação. d. Reforço. e. Divisão. f. Posposição.

60. Inscrição da hipoteca. Ações a que dá margem. Extinção da hipoteca.

\section{Direito de Família}

Parte I

\section{Introdução}

01. Família. Origem, evolução, importância. Acepções do vocábulo. Família legítima. Natureza jurídica. Proteção legal.

02. Direito de Família. Noção, conteúdo, objeto. Caráter das disposições que o regem. Direitos de família. Perspectivas da futura regulamentação. 
Parte II

Do casamento.

\section{Título I \\ Generalidades.}

03. Casamento. Noção. Elementos históricos. Definição. Natureza jurídica. Caracteres.

04. Da promessa de casamento ou esponsais. Desfazimento e ruptura. Conseqüências.

\section{Título II \\ Impedimentos.}

05. Noção geral e classificação. a. Impedimentos dirimentes públicos.

06. b. Impedimentos dirimentes privados. c. Impedimentos meramente proibitivos. Da oposição de impedimentos e sua prova.

\section{Título III}

Celebração. Formalidades. Prova. Disposições Penais.

07. Casamento civil. Formalidades preliminares e formalidades do ato.

08. Casamentos: a. em caso de moléstia grave. b. Casamento urgente. c. Em iminenteperigo de vida. d. Por procuração. e. Casamento perante agentes diplomáticos e consulares.

09. Casamento religioso com efeitos civis.

10. Prova do casamento celebrado no Brasil e no estrangeiro. A posse do estado de casado. Sanções penais e civis relativas ao casamento. 


\section{Título IV \\ Efeitos do Casamento. \\ Capítulo I \\ Em relação aos cônjuges}

11. Disposições gerais. Deveres recíprocos dos cônjuges.

12. Chefia da sociedade conjugal. Deveres e direitos do marido.

13. O poder doméstico. Condição jurídica da mulher casada.

14. Direitos da mulher casada. Deveres como companheira, consorte e colaboradora.

15. A mulher na chefia ocasional da sociedade conjugal. Responsabilidade pelos atos por ela praticados.

\section{Capítulo II}

\section{Em relação aos bens}

16. Do regime dos bens entre os cônjuges. Disposições gerais. Pactos e doações antenupciais.

17. Os regimes de bens em espécie: a. comunhão universal.

18. b. Comunhão parcial.

19. c. Separação de bens. O regime de separação imposto por lei.

20. Dotal. Aqüestos. Necessidade de uma reformulação das disposições.

\section{Título V \\ "Sucedâneos" do Casamento.}

21. Os substitutivos mais usados, de maneira particular o "casamento por contrato" e o concubinato. 


\section{Título VI}

\section{Dissolução da Sociedade Conjugal.}

22. Modos pelos quais termina a sociedade conjugal. Generalidades. A morte de um dos cônjuges. O problema da ausência.

\section{Título VII \\ Segundas Núpcias.}

23. Segundas núpcias. Efeitos.

\section{Título VIII \\ Inexistência, Nulidade e Anulabilidade.}

24 Casamento inexistente e casamento nulo. Nulidade do casamento religioso.

25. Casamento anulável.

26. Efeitos da nulidade e da anulação do casamento. Casamento putativo.

\section{Título IX \\ Desquite. O Problema do Divórcio.}

27 Desquite por mútuo consentimento.

28. Desquite litigioso. A prévia separação de corpos.

29. O problema do divórcio.

\section{Título $\mathrm{X}$}

\section{Situação dos Filhos.}

30. Guarda e proteção dos filhos. 


\section{Parte III}

\section{Do parentesco}

\section{Título I}

Noções Introdutórias.

31. Parentesco. Disposições gerais. Contagem de graus.

\section{Título II}

\section{Filiação.}

32. Filiação. Conceito. Importância. Filiação legítima e sụa prova.

33. Filiação ilegítima. Legitimação. Reconhecimento voluntário.

34. Investigação de paternidade e de maternidade.

35. Adoção.

36. Legitimação adotiva.

37. O pátrio poder.

\section{Título III}

\section{Alimentos.}

38. Alimentos.

\section{Parte IV}

Tutela, curatela, ausência.

39. Tutela. Curatela.

40. Ausência. 
Direito das SucEssões.

\section{Parte I}

\section{Introdução}

01. Sucessão. Conceito. Acepções da palavra. Direito das sucessões. Noção, histórico, fundamento, elementos.

\section{Parte II}

Da sucessão em geral

02. Sistemática do Código. Espécies de sucessão hereditária. Herdeiro e legatário.

03. Abertura da sucessão. Comoriência. Capacidade para suceder. Sucessões irregulares.

04. Herança. Adição.

05. Aceitação e renúncia da herança.

06. Herança jacente e herança vaga.

07. Dos que não podem suceder.

\section{Parte III}

Da sucessão legítima

08. Generalidades. A ordem da vocação hereditária. A sucessão do filho adotivo e a do adotado legitimamente. A sucessão da companheira.

09 Usufruto vidual.

10. Direito de representação. 


\section{$-77-$ \\ Parte IV \\ Da sucessão testamentária. \\ Títuld I \\ Generalidades.}

11. Definição e caracteres do testamento. Da capacidade testamentária ativa.

Título II

Formas de Testamento.

Capítulo I

Ordinárias

12. a. Testamento público.

13. b. Cerrado. c. Particular. Codicilos.

Capítulos II

Especiais

14. a. Marítimo. b. Militar.

Capítulo III

Das disposições testamentárias

15. Interpretação. Cláusulas de inalienabilidade, incomunicabilidade e impenhorabilidade.

Títula III

Dos Legados.

16. Dos legados.

17. Dos efeitos dos legados e seu pagamento.

18. Da caducidade dos legados. Direito de acrescer. 


\section{Título IV}

\section{Capacidade Testamentária Passiva.}

19. Da capacidade de adquirir por testamento.

20. Dos herdeiros necessários. Legítima.

\section{Título V}

\section{Da Execução do Testamento.}

21. Vícios. Captação da vontade. Nulidades.

22. Da redução das disposições testamentárias.

23. Das substituições. Fideicomisso.

24. Da deserdação. Rompimento e revogação dos testamentos.

25. Do herdeiro aparente.

26. Do testamenteiro.

\section{Parte V}

Do inventário e partilha

27. Do inventário. Da partilha. Dos sonegados.

28. Das colações. Do pagamento das dívidas.

29. Da garantia dos quinhões hereditários. Da nulidade de partilha.

\section{Parte VI}

Da ação de petição de herança

30. Ação de petição de herança. 